\title{
Just Kids? Peer Racism in A Predominantly White City
}

\author{
JAMES BAKER
}

\begin{abstract}
This article examines the effects of racialized name-calling on a group of twelve visible minority refugee youth from Newfoundland and Labrador, Canada. Through one-onone in-depth interviews, the author discusses their experiences in order to better understand how this important group of adolescents conceptualizes, constructs, and copes with racism while living in a highly homogeneous white Canadian city. The author concludes by noting that these experiences are having a negative effect on their social integration and that increased efforts by teachers and administrators are needed to help combat peer racism in this predominantly white city.
\end{abstract}

\section{Résumé}

Cet article examine les effets des injures raciales sur un groupe de jeunes réfugiés de douze minorités visibles de Terre-Neuve-et-Labrador, au Canada. À l'aide d'entrevues individuelles approfondies, l'auteur examine leurs expériences dans le but de mieux comprendre comment ce groupe important d'adolescents comprend le racisme et négocie cette réalité dans le cadre de leur intégration dans une communauté urbaine canadienne blanche et homogène. L'auteur arrive à la conclusion que ces expériences ont un effet négatif sur leur intégration sociale, et que les enseignants et administrateurs doivent fournir un effort supplémentaire pour lutter contrer le racisme par les pairs dans une ville canadienne blanche, telle que St. John's.

\section{Introduction}

Over the past few years, the role that immigration can play in sustaining Canada's, and specifically Newfoundland and Labrador's, population has been well documented. ${ }^{1}$ The province, however, has had problems in attracting and retaining immigrants; in fact, in 2009, Newfoundland and Labrador attracted less than 1 percent of the total immigration population arriving in Canada. ${ }^{2}$ This process is further complicated by the fact that as many as 70 percent of those who arrive in Newfoundland and Labrador leave within the first year. ${ }^{3}$ Coupled with this exodus is a low provincial retention rate which, according to a report completed for Citizenship and Immigration Canada, averaged about 43 percent from 2000 to $2006 .{ }^{4}$ Still, Newfoundland and Labrador continues to slowly increase its immigrant and refugee population, especially from such areas as Asia, Africa, and South America. In 2002, for example, 404 immigrants arrived in the province while in 2011, that number had increased to $682 .{ }^{5}$ Indeed, as the province continues to diversify, there is no doubt that the issue of racism will gain greater public salience.

While many Canadians take pride in the belief that Canada is viewed as a country that promotes immigration and multiculturalism, the fact remains that racism does exist within contemporary Canadian society. ${ }^{6}$ Ibrahim M. Alladin argues that many visible minorities living in large urban centres (such as Toronto, Montreal, and Vancouver) have experienced widespread discrimination in housing, employment, and education. ${ }^{7}$ In fact, a 2005 poll conducted by the Dominion Institute and Ipsos Reid suggests a shift in those targeted by racism. In 1993, it was reported that Canadians felt that African-Canadians were the most likely population to be discriminated against; however, by 2005, that view had shifted towards individuals from the Middle East. ${ }^{8}$ Regionally, the same poll found that 15 percent of Atlantic Canadians felt they had been a victim of racism while 10 percent believed that racism had increased in Atlantic Canada in the past five years. While research and polling on racism tend to focus on the experiences of visible minority adults, there is still a paucity of research on the experiences of adolescent visible minorities, especially 
younger refugees living in a smaller urban centre like St. John's, Newfoundland and Labrador. Indeed, the focus on refugee youth is especially important given the fact that numerous studies have identified the effect that racism has on the lives of visible minorities. ${ }^{9}$ As Varma-Joshi and her colleagues note, "Studies suggest that children are aware of racial differences, can cite experiences in racism, hold racial preferences, and demonstrate discriminatory behaviour as early as four years old."10

The purpose then of this study is threefold: to understand how adolescent refugees conceptualize racism; to describe the nature of racism as experienced by those living in a predominantly white city; and to examine their coping responses to racist incidents. The specific questions asked were: How do self-described adolescent victims of racism conceptualize the term? What is the nature of racism as experienced by self-described adolescent victims of racism in the St. John's Census Metropolitan Area (CMA)? How do selfdescribed adolescent victims of racism respond to perceived racist incidents? In order to address these research questions, this article focuses on the experiences of twelve refugee youth aged fourteen to twenty who were enrolled in three junior and senior high schools in St. John's, Newfoundland and Labrador. ${ }^{11}$

This research was partly driven by a desire to better understand the nature of racism as experienced by adolescent refugees living in a small urban centre (defined in this study as having a CMA population of less than 200,000) as well as to contribute, in a small way, to the literature on racism. ${ }^{12}$ This article was also conceived, in part, after a discussion with individuals who are associated with, and work for, the Association for New Canadians. After several discussions with the Association's Settlement Team, it was becoming quite clear that racist incidents among refugee youth were increasing within the St. John's CMA.

Given the similarities between New Brunswick and Newfoundland and Labrador, and the desire to research racism in a smaller centre, it was thought that replicating the methodological approach of Cynthia Baker's New Brunswick study would be both useful and practical. ${ }^{13}$ Generally speaking, both New Brunswick and Newfoundland and Labrador have a relatively homogeneous population (although New Brunswick has a more visible Aboriginal population located closer to the major population centres of Fredericton, Moncton, Saint John, and Miramichi). In terms of population, Newfoundland and Labrador has approximately 514,000 residents with 196,000 of these individuals located within the St. John's CMA while New Brunswick has an approximate population of 751,000 with 138,000 located in Moncton, 127,000 located in Saint John, and 94,000 in Fredericton. ${ }^{14}$ Furthermore, based on the 2006 census, the total immigrant population in Newfoundland and Labrador is estimated to be 8,380 (representing approximately 2 percent of the total provincial population) which is relatively comparable to New Brunswick (its total immigrant population is estimated to be 26,359 representing approximately 4 percent of the total population). ${ }^{15}$ As these numbers will also include immigrants from the United States of America, the United Kingdom, and other white European countries, the number of visible minorities who are newcomers will be invariably lower.

\section{Sampling and Methodology}

This research involved twelve Government Assisted Refugee (GAR) adolescents aged fourteen to twenty (from geographic areas that include Eastern Europe and South Asia [n=4], Africa and Middle East [ $n=4]$, as well as South America $[n=4]$ ) who were residing in St. John's, Newfoundland and Labrador at the time of the study. A potential participant was described as a visible minority GAR youth who believed her/himself to be a victim of a racist incident. One of the key issues for this research was agreeing on a proper definition of youth. For example, a cursory review of Statistics Canada reports suggests that the definition of youth can range anywhere from fourteen to thirty-five, depending on the research, and even the United Nations Educational, Scientific and Cultural Organization (UNESCO) differs in its assessment (using fifteen to twenty-four in some instances and fifteen to thirty-five in others). ${ }^{16}$ As such, for the purposes of this study, youth will be defined as fourteen to twenty-five, based on Statistics Canada's National Longitudinal Study of Children and Youth.

In order to secure potential participants for the research, GAR youth were contacted with the assistance of the Association for New Canadians, a non-profit, communitybased settlement agency located in St. John's, Newfoundland and Labrador. As the main settlement agency in the province, it was believed that they would be best positioned to help identify youth who would be able to address the research questions. The Association's Settlement Social Worker made an initial contact with potential participants and, if the individual agreed to participate, the researcher followed up shortly afterwards. In an attempt to achieve as large a sample as possible given the research limitations, the snowball technique was utilized. With this process, existing study subjects recruit future subjects from among their acquaintances. This was especially important given that the population was uncharacteristically small (i.e., selfidentified victims of racism aged fourteen to twenty among a refugee youth population of approximately one hundred at the time of the study). While this technique is useful in managing the characteristics of a sample, it would be nearly 
impossible to balance the sample by location, age, or gender. Moreover, due to the small sample size, the schools remain unidentified in order to maintain participant anonymity. The final sample included seven females and five males from Kyrgyzstan, Liberia, Ukraine, Sierra Leone, Colombia, Iraq, and India.

Researching youth is especially important given that the millennial generation (those born post-1980) are the largest, most racially diverse generation in Canada. There is no doubt that such changes will have important implications for smaller provinces like Newfoundland and Labrador which remains largely (greater than 95 percent) homogeneous and may experience resistance from the local population as it continues to diversify. ${ }^{17}$ Furthermore, for those who arrive in Canada as refugees, asylum seekers, or lowskilled immigrants, research conducted by the Canadian Race Relations Foundation found that the unemployment rate is higher among foreign-born visible minorities and Canadian-born visible minorities than their white counterparts, that good jobs remain elusive for minorities, that higher education offers fewer payoffs for minorities, and that racism, especially subtle racism, continues to be a factor in the workplace. ${ }^{18}$ Finally, refugee youth are an important cohort for study given that there is so little research on this group within either the Canadian or Atlantic Canadian context.

Table 1: Youth Participants

\begin{tabular}{lll}
\hline Gender & Age & Source Country \\
\hline M & 14 & Ukraine \\
F & 18 & Kyrgyzstan \\
M & 18 & Kyrgyzstan \\
M & 18 & Liberia \\
F & 17 & Liberia \\
M & 18 & Colombia \\
M & 14 & Colombia \\
F & 14 & Colombia \\
F & 20 & Sierra Leone \\
F & 17 & Colombia \\
F & 15 & Iraq \\
F & 15 & India \\
\hline
\end{tabular}

Each of the twelve participants engaged in an in-depth one-to-one interview on the subject of racism. Interviews were chosen as the preferred method of research for a number of reasons: first, it was felt that other methods (such as focus groups) would limit the discussion given that the research addressed a sensitive topic; second, with the interview process, the researcher could ensure both confidentiality and anonymity (which would not be the case with focus groups); and third, given scheduling limitations, the interview process proved to be most effective for the interviewees (it is easier to schedule for one person rather than to try to schedule for a group).

To ensure that no problems arose during the interview, responses were recorded via both hand and tape. Although the questions were predetermined, the interviewer had flexibility in following up on related topics, and in order to ensure consistency, the author conducted all the interviews. In order to get a reasonable sample, some interviews were conducted via telephone. This proved to be highly convenient for the interviewee given that the interviews were conducted during the exam period for the students, thereby allowing them to participate in the research while ensuring minimal disruption to their studies. The author also believed that the telephone interviews put an emotional distance between the interviewer and the interviewee, allowing for a freer discussion on racism. Unfortunately, phone interviews were not practical for all participants given that the English language skills of some interviewees were limited. It is important to note that interpreters were not used as the researcher wanted to ensure that the interviews reflected, in their own words, participants' lived experiences. As such, the sample was further limited to those youth whose understanding of English was strong enough to be able to communicate reasonably well in English.

Prior to taping the telephone interviews, the consent form was verbally read to the potential participant and then the participant's desire to continue with the interview was audio recorded. The research assistant then followed up with a sealed written consent form that was provided to the student at their respective school for their signature. For the in-person interviews, youth were given a copy of the consent form and asked to read it. If they did not have any questions, and agreed to participate, they were asked to sign and date the document.

Data was collected from the participant interviews and interpreted using a hermeneutical methodology. ${ }^{19}$ This approach is most useful when one wishes to understand what it means to be a victim of racism. As Varma-Joshi, Baker, and Tanaka note, "In a hermeneutical framework, interviews are treated as texts created by participants who were engaged in the particular experience being studied." 20 Texts were first treated as a whole, then were broken into relevant parts. These parts were constantly read and reread as the data was divided into categories in order to develop relational patterns. Indeed, Allan and Jensen note that textual interpretation is at the core of a hermeneutical framework given that "the purpose of a hermeneutical description 
and explanation is to achieve understanding through interpretation of the phenomena under study." 21 As part of the constructivist inquiry paradigm, hermeneutics is useful in that it presumes that individuals bring a body of prior knowledge to new situations. Assessing the participants' prior understanding of racism was crucial, as this would not only help frame their experiences, but also contribute to a better understanding of their reality living within a predominantly white city. It is important to note that given the small sample size, the research cannot be generalized to the entire refugee youth population in the province or even St. John's; rather, the intent is to allow for a better understanding of how this particular group of refugee youth conceptualize, construct, and cope with racism while living in a relatively homogeneous white city.

\section{“Old" versus "New" Racism}

The contemporary scholarly consensus suggests that the concept of race is a modern phenomenon. ${ }^{22}$ Ian Law, however, suggests that racism has existed in numerous forms across the globe since antiquity. For example, commenting on Middle Eastern racism, he notes, "Ancient Hebrews thought interbreeding between natural kinds abhorrent ... [and the] biblical story of God cursing black Africans with eternal slavery ... has been used as the single greatest justification for slavery for millennia." ${ }^{23}$ Law further argues that Christian European racism has its origins in the expulsion of the Jews and Moors from Spain and that racism has existed in China and Japan as far back as feudal times. In effect, Law's assessment challenges the notion that "old" racism has its origins in European colonialism. ${ }^{24}$

The idea of "old" racism (as juxtaposed against the idea of "new" racism) can be best described as "a belief that race is the primary determinant of traits and capacities and that racial difference produce an inherent superiority of a particular race." 25 While racism can exist at multiple levels including institutional, environmental, cultural, and interpersonal, identifying individual racism may be problematic given that its identification is invariably based on one's perception of a situation and/or interaction. Whether institutional or individual, Ying Yee argues that while racism is a social construct, it does carry meaning within contemporary society, thereby influencing the ways in which individuals interpret and define the term. Hence, the definition of "old" racism is often based on skin colour, culture, nationality, or religion. ${ }^{26}$

This research, however, proposes that the key to assessing racism in contemporary Newfoundland and Labrador society is to apply Teun van Dijk's "new (or subtle)" racism. Van Dijk's theory can help to explain the potency of such concepts as fitting in, passing, and blaming the victim.
Indeed, the concept of "new" racism is best conceptualized as the idea that "traditional forms of racism, based on explicit beliefs in white superiority, have been giving way to new forms of racism, which are more subtle than traditional forms, and which in many cases (though by no means all) rely on discourse rather than violence and segregation...." 27 Whereas traditional racists exhibit a direct and overt pattern of discrimination, the "new' racists" actions may appear variable and inconsistent. As Dovidio and Gaertner point out, "Sometimes ['new' racists'] do not discriminate, reflecting their egalitarian beliefs; other times, they do discriminate, manifesting their negative feelings." 28

By exploring the concept of "new" racism, van Dijk argues that latent racist messages can exist everywhere, yet in some popular manifest perspectives, exist nowhere. For van Dijk, racist messages "are expressed, enacted and, confirmed by text and talk, such as everyday conversations, board meetings, job interviews, policies, laws, parliamentary debates ... movies, TV programs and news reports in the press, among hundreds of other genres." 29 Thus the idea of a "new" racism can potentially provide important insights regarding the existence and influence of latent or subtle racism on adolescent refugees living in a small white urban centre.

Indeed, such contemporary racism is, as Barker argues, masked in racially neutral language and rearticulated to make it more acceptable in public discourse. ${ }^{30}$ This "new" racism is most potent because it reflects a subtle, continued form of prejudice-even though an individual may not recognize that her/his actions are causing anguish. Indeed, as Phil Fontaine notes, "particularly in politics, racism and prejudice are always founded on seemingly rational, strategic arguments, designed to appeal to 'common sense' and so-called logical thinking." ${ }^{31}$ His assessment implies that the prejudices, upon which such racist arguments are based, seem acceptable.

Philomena Essed also argues that the micro forms of racism have their origin in the macro forms; in other words, it is the inherent structural inequalities and historical processes that have led to the micro forms of racism. Such everyday racism is especially hurtful because it represents something that may not be consciously experienced by its perpetrators; it can occur without thought and be dismissed when attention is brought to it. It integrates itself into everyday practices and over time becomes part of the expected, the unquestionable, and the habitual. It represents "the empty seat next to a person of colour which is the last to be occupied in a crowded bus, the slight movement away from a person of colour in an elevator, [and] the over attention to the Black customer in the shop...."32 Indeed, everyday racism is quite similar to the concept of "interpersonal 
context" as described by Shelly Harrell, who argues that "at the interpersonal level, racism is manifested through both direct and vicarious experiences of prejudice and discrimination. This involves interactions with other people, as well as observation of their actions, nonverbal behaviour, and verbal statements." 33 While everyday racism (or interpersonal context) may be subtle, invisible, and ethereal to those who perpretrate it, for those who experience it, everyday racism is obvious, visible, and substantial.

It is important to recognize that everyday racism cannot simply be reduced to a singular event. It is a systemic process that works through multiple interactions, situations, and experiences. Indeed, many of the young interviewees identified multiple everyday racist experiences that, to the outside observer, might appear innocuous but to the young refugee, they can have a lasting and significant effect. As Henry et al. note, "These [everyday racist] incidents are difficult to quantify because they are only revealed in the thoughts, feelings and articulations of victims...." 34

\section{“Maybe I Do Something Wrong": Young Refugees' Conceptualization of Racism}

Given that hermeneutics presumes that individuals bring a body of prior knowledge to new situations, it was important to understand how adolescent refugees conceptualized racism. Indeed, Essed argues that the meaning attached to specific racist events can only have significance within a framework of one's general understanding of racism. ${ }^{35}$ For those youth from Colombia, their racist experiences in St. John's reflected a well-known negative Colombian stereotype. For example, the Colombian youth noted that their peers oftentimes made disparaging comments about their country and its connection to the drug trade. As one female student noted:

\footnotetext{
...well Colombia is known for its drug thing, the drug trade and all that because people assume that if you come from a place you necessarily, you know, do things that some other people have done so sometimes people ask me about drugs and they make constant comments about you know about being related to drugs and cocaine and marijuana or stuff like that ... they'll ask me if I have some or if I grow it at home or if I smoke it.
}

This statement is perhaps an excellent example of a "lesser" form of racism (assuming that there are even "degrees" of racism). For the individual making the comment, it may be viewed as harmless (or merely a source of curiosity) but for this young refugee, it speaks directly to her identity. In fact, the Colombian youth interviewed in this research were highly cognizant of the "Colombian stereotype," and felt that comments such as the one above continued to perpetrate an overall negative image of Colombian refugees.

Similarly, the three African youth interviewed for this research conceptualized racism in terms of their skin colour. Moreover, one Liberian youth indicated that there were "levels" of racism in the province, and he perceived blacks to be at the base of that racial hierarchy. He states that racism is:

...physically by color [be]cause, um, especially black and white, because if you are white and you're from Mexico they [white people] won't treat you differently because you're white, but if you're black [laughs] and you're from, and you [don't] look like white people, they treat you differently because of your color....

This statement suggests that the interviewee perceives individuals from South America as on a par with other white youth. Obviously, as the interviews indicate, Colombian students do not share this view.

Another interesting problem with conceptualizing racism stemmed from the fact that two respondents had difficulty understanding the term. While both of these individuals had little trouble recognizing the fact that they were viewed as different in St. John's, having arrived from a country where they were the majority, racism, as a concept, was foreign to them. Such a view is supported by Essed, who notes that "it may be assumed that, without general knowledge of racism, individuals cannot comprehend the meaning of racism in their lives." 36

While they were unable to conceptualize racism, the negative effect it has had on them was nonetheless compelling:

Interviewer: When I ask about the word racism, what image comes to mind or what ... how would define racism or how do you see racism?

Interviewee: Racism? Umm ... I don't know what it means.

Interviewer: How would you describe when someone treats you differently?

Interviewee: Mistreating me? (Yeah) okay, it's like treating me badly (uh-huh) yeah (long pause) umm maybe someone does not like me (okay) umm maybe sometime I may do something wrong and the person does not understand and maybe... I don't know...

This exchange speaks volumes regarding the problems that newcomers, especially refugees, face when coming to Canada. Two of the three African refugee youth who were interviewed were at a loss to explain why some individuals reacted this way when, 
... as for you, you said racism right [nervous laugh] ... I don't know the meaning of the word too good ... so if anybody tells such a thing that it would not feel good ... what action I would take against the person if somebody ... somebody to tell me I didn't do anything to them.

Obviously, they recognize the emotional distress that racism can cause, despite their inability to "name" it.

Finally, while one Eastern European interviewee described a racist experience that was not directed toward him (rather toward a Chinese student in his class), he was nonetheless cognizant of the harm it can cause. ${ }^{37} \mathrm{He}$ states,

you don't expect people to think [about people like that] and when people think something like that about someone who's different, I'm different from the others, I look like Chinese too, and you just ... I feel like something like that might happen [to] me, and there's going to be bad things said about me for nothing.

For his sister, however, her experience with racism was reflected through her nationality, which she recognized as making her different. She went on to describe her experience as one in which her female peers would give her demeaning glares - a prime example of the overt nature of everyday racism.

Sadly, some students in the sample perceived their racist experience as a result of their own actions. As the female Liberian youth noted, "I used to say umm 'I think most people doesn't like Blacks' and he'd [her brother] just say 'maybe no they don't want to talk to you because you just came here' and I was like 'yeah, maybe'." Such experiences may be rooted in the discourse of blaming the victim. As Frances Henry and her colleagues note, "In this form of dominant discourse, it is assumed that certain communities (such as African Canadians) lack the motivation, education, or skills to participate fully in the workplace, educational system, or other arenas of Canadian society." 38

\section{“I Don't Like Blacks": Young Refugees' Experience with Racism}

While it was a relief to find that none of the interviewees had experienced any violent racist incidents (in contrast to the study by Baker, Varma-Joshi, and Tanaka), there was, however, concern over the number of incidents in which racial slurs were used. During the interviews, seven youth described an incident where they were subjected to a racial slur. In one incident, a female youth described how another student would not help her find a classroom because she was black:
I want[ed] to go to the ESL to see [name removed] but I thought she didn't say anything and I just put my hand on her shoulder, she was like 'Leave me alone' and I said 'Why? Can you please direct me somewhere?' and she said 'I don't want to direct you.' I said 'Why?' she said 'I don't know you' I said 'I want you to be my friend. You can direct me because I don't know anyone here.' She said 'I don't like blacks.' And I said 'Because I'm black.' She was like 'Yeah.'

Another youth reported that she remembered being called a "P_i" and an "Oreo Cookie" in elementary school. 39 Clearly, such examples go beyond the covert form of racism to a point where the individual wanted to ensure the victim knew that they were the "outsider." These racial slurs were not limited to youth of colour as four other students reported being persecuted due to their religious practices. As noted earlier, one youth noted that he was picked on for not being Jewish (while living in Israel) while a Muslim youth in the sample noted that she had been called a terrorist numerous times because she wears a hijab. As Picca and Feagin suggest, there are some whites who "engage in racialized performances to show people of color that they are trespassers into white space." 40

The remainder of the sample described being subjected to anti-immigrant sentiments, stereotypes, and discrimination. The anti-immigrant comments ranged from such statements as "immigrant go home" and "you're not wanted here" to "go back to your country" and "stop killing my language." These stereotypes were reflected mostly in the comments made by the Colombian interviewees who noted that they had been subjected to numerous references about the drug trade in Colombia. In fact, when asked if there had been other racist incidents in his life, one youth responded, "Well [pause] mostly comments people make about my [pause] my country, and like my color, and stuff like that, like they make a lot of comments about drugs and stuff like that."

Finally, one of the interviewees recounted being subjected to discrimination while applying for a job in St. John's. Despite her belief that she was qualified, she felt that she was not hired due to her skin colour. She notes that she felt "like they [the business] are really racist in that place because they hadn't picked me, but it's not even in the context, that place is, like a public place." In fact, the particular individual went on to note that, from this experience she would not feel comfortable applying again for a job in the province.

\section{"You Just Try To Be Like Everyone Else": Coping with Racism}

Much research has been conducted on the social and mental effects of racism on visible minority adolescents. ${ }^{41}$ For youth of all ethnicities, adolescence can be a difficult 
time; indeed, it becomes more acute when adolescent refugees have to deal with the added pressures produced by their race or ethnicity. One of the more troubling results of racism is the sense of loneliness and isolation it can create. As Rokach and Neto note, "Loneliness has been linked to such maladies as depression, suicide, hostility, alcoholism, poor self-concept, and psychosomatic illnesses...." 42 Furthermore, Brennan has noted that "adolescence seems to be the time of life when loneliness first emerges as an intense recognizable phenomenon." 43 while Feagin and his colleagues have suggested that racism, as experienced by visible minority youth, has resulted in a higher degree of isolation, alienation, segregation, and concomitant stress. ${ }^{44}$ Brondolo and her colleagues indicate that racism can be a significant source of stress and may have "deleterious effects even when the target does not consciously perceive the maltreatment or attribute it to racism." 45 Indeed, those affected by racism must not only cope with the substance of racism (e.g., interpersonal conflict, blocked opportunities, and social exclusion) but also must manage its emotional consequences (e.g., painful feelings of anger, nervousness, sadness, and hopelessness).

In these interviews, the youth respondents expressed feelings of embarrassment, hurt, sadness, uneasiness, and shyness. These feelings can also influence their development and lead to an increased sense of loneliness. One young refugee noted that after experiencing the initial racist incident, he remembered being sad and moody. He went on to note that racism "makes me feel not good about myself, like, I don't know, makes you think, like, that you don't deserve to be like everyone else and all that." Surprisingly, only two interviewees indicated that their experience with racism made them angry-a natural response given the seriousness of the issue. ${ }^{46}$

Another refugee youth suggested that he had to "act white" in order to be accepted; indeed, this acceptance would come at the expense of his own identity. Indeed, the coping tasks posed by racism may create a need to manage the damage to one's self-concept and social identity. ${ }^{47} \mathrm{He}$ states, "You know like you don't always like being the one who is outside who is like you know ... it's like you and everybody else ... so you just like try to be like everyone else is...." This too has serious implications for Canada given the emphasis that is placed on promoting multiculturalism as an official policy. If young refugees feel that they need to "act white" in order to fit in with Canadian society, then this directly challenges the very notion of Canada as a multicultural mosaic. Indeed, his sentiment mirrors the anecdotal evidence as reported by settlement counsellors at the Association for New Canadians in Newfoundland and Labrador. They have observed that some African youth have adopted the African
American identity-perhaps as a means to fit into "traditional" North American society and to adopt traditional behavioural norms associated with that identity. ${ }^{48}$

Two trends deal with the way in which these youth address the emotional pain created by these experiences. First, there appears to be a tendency for these young refugees to dismiss their experience with racism by attempting to ignore the comments and incidents. Second, and perhaps even more serious, reflects the fact that their parents are also encouraging this behaviour. The majority of those interviewed indicated that their parents advised them to forget about their experience, and even suggested that it was not all that important. As one youth noted, "They [his parents] said that we just had to get used to it because ahh ... like racism really exists everywhere all around the world." If these youth bottle up the associated feelings they have with racism, it may create greater emotional and social problems for them in the future. Interestingly, evidence suggests that specific coping mechanisms may be culturally based. Brondolo et al. reported that while black Americans would "try to do something and talk to others" in response to a racist incident, Asian immigrants in Canada would prefer to "regard it as a fact of life, avoid it or ignore it."49

While some youth in this sample felt the need to ignore the pain of racism, others sought social supports from their family and friends. Social supports are defined as the presence or availability of network members who express concern, love, and care for an individual and provide coping assistance. ${ }^{50}$ Seeking social support involves communicating with family and/or friends about the experience, and many of the youth interviewed indicated that they had the support of their friends in dealing with racism in St. John's. While they recounted there were times when they felt they were an outsider, the fact remains that they do have some degree of peer support. Several students indicated that their friends came to their defense during the racist incident and provided support following it. This is especially important to young refugees since it may give them cause to believe that not all of their white peers espouse racist attitudes or beliefs, and that their adopted country will support and protect them.

\section{Discussion and Conclusion}

This paper sought to answer three key questions: "How do self-described adolescent victims of racism conceptualize the term?", "What is the nature of racism as experienced by self-described adolescent victims of racism in the St. John's CMA?", and "How do self-described adolescent victims of racism respond to perceived racist incidents?" It is evident that these refugee youth understand the nature of racism and are able to conceptualize it despite the fact the some 
respondents appeared unable to comprehend the term. Moreover, the nature of their experiences seems to fall directly into the scope of "new" racism although one individual's experience could be considered to be institutional racism. Finally, the coping strategies of these youth varied ranging from accepting and/or ignoring it to seeking out social supports.

Indeed, the connection between the respondents' vision of racism and their own experiences is especially powerful. They recognized that racism was having a negative effect on their lives, and was creating an environment where they did not feel welcome. In fact, one of the observations made by the researcher was that the interviewees generally became quiet and withdrawn when describing their experiences. This can become problematic if these experiences begin to occur on a regular basis, especially for the younger respondents (i.e., younger than sixteen), if they choose not to discuss their experiences, or if they choose not to seek out peer or family support.

The evidence also suggests that the described experiences have the potential to go beyond the spectre of everyday/"new" racism and may reflect the possibility that a virulent overt racism is developing in the city. Indeed, a report prepared for the Association for New Canadians found that over 40 percent of white youth in the St. John's CMA felt that racism was a problem at their school. ${ }^{51}$ Such statistics are especially relevant as St. John's seeks to move away from its traditional monocultural (i.e., English/Irish) demography to one that is more reflective of the Canadian mosaic. While the majority of Canadians may believe that Canada is generally devoid of prejudice, discrimination, and racism, the evidence presented here, at least among a select group of St. John's refugee youth, appears to contradict that assertion. Clearly, there is a discrepancy between the perceived and the actual degree to which racism is a problem within the city. Indeed, each respondent felt that racism created an environment where they did not feel welcomed or where they could not be viewed as equal to their white peers. Beyond the traditional problems associated with language and culture, refugee youth also have to deal with the issues that follow from experiencing racism.

The experiences of racism also differed among the various ethnic groups. For Middle Eastern and Indian youth, their belief system and religious practices were most likely to be attacked by their peers and their conceptualization of racism reflected this view. Moreover, the Eastern European and Colombian students seem less likely to experience racism on a level similar to African students, though the impact is perhaps just as devastating. Evidence from Warren et al. suggests that this could result from the fact that these individuals are more accepted due to the homogeneity of their culture and language in relation to their white peers..$^{52}$

Racism, either real or perceived, can also affect young refugees by creating undue stress in their lives. Indeed, it is the accumulation of racism-based stress that can have the most devastating effect. As Harrell notes, "The stress-and potential damage - of racism lies not only in the specific incident but also in the resistance of others to believing and validating the reality or significance of one's personal experience." ${ }^{33}$ The reliving or retelling of the experience to someone who is doubtful can create added stress beyond the original event. Moreover, persistent racism can significantly impact the social and mental well-being and development of youth by influencing their ability and willingness to trust, to form close relationships, and to be part of a social group. It can also influence their overall academic performance.

The research demonstrates that racism has had an immediate, and in some cases, long-term effect. Many respondents indicated that they felt ashamed about being different from their white peers and that the comments oftentimes resulted in a poor self-image. When asked about how the racist comments made them feel, one student responded that "sometimes it makes me feel bad because I'm not doing anything wrong. I'm just being here." As an adolescent refugee to Canada, developing a poor self-image at such a critical stage in the integration process may have serious implications for his later emotional and cogitative development.

Another consistent observation emanating from the interviews was the respondents' belief that education can help to eliminate racism and that community groups have an important role to play. The respondents spoke about the types of events in their schools as well as the education seminars that take place. Indeed, March 21, the International Day for the Elimination of Racial Discrimination, was cited by many of the youth as an important part of the school year for them. Furthermore, settlement agencies, such as the Association for New Canadians, have done a tremendous job in developing programs to educate youth on such key topics as racism, multiculturalism, and cultural diversity. Yet, despite all the programs, events, and training designed to promote diversity, racism still looms large.

The interviews clearly demonstrate that adolescent refugees are experiencing increased instances of racism in St. John's, and perhaps more seriously, this racism is peer driven. Indeed, the effect that racism can have on the mental health of these refugee youth is immense and can seriously impact their integration into Canadian society. It is also perhaps likely that the limited racial diversity found in Newfoundland and Labrador may diminish the critical 
impact of the interviewee's experiences. As such, given the lack of a familiar ethnocultural community, this may result in an increased mental strain on young visible minorities, especially given the tendency for the youth in this sample to cope with the racialized name calling by accepting and/ or ignoring it.

While it was anticipated that racism would exist in the city, it was disconcerting to realize its overall effect on young refugees. Both this study and the one conducted by Baker, Varma-Joshi, and Tanaka suggest that racism does have immediate and long-term mental and social consequences for adolescents. ${ }^{54}$ It is hoped that this research will not only help to increase the knowledge of the effects of racism in a predominantly white city but also provide the necessary impetus for teachers and administrators to act to address it sooner rather than later.

\section{Notes}

1. Wade Locke and Scott Lynch, A Survey of the Attitudes of Employers in Newfoundland and Labrador Toward the Recruitment and Employment of New Canadians and International Workers (St. John's: Leslie Harris Centre of Regional Policy and Development, 2005), accessed 25 October 2009, http://www.mun.ca/harriscentre/reports/ research/2006/immigartion_final_report.pdf; Goss Gilroy Inc., Retention and Integration of Immigrants in Newfoundland and Labrador-Are We Ready?(St. John's: Atlantic Canada Opportunities Agency and the Coordinating Committee on Newcomer Integration, 2005), accessed 25 October 2009, http://www.nlimmigration.ca/media/2854/ immigrationstudyfinal.pdf; Government of Newfoundland and Labrador, Office of Immigration and Multiculturalism, Diversity Opportunity and Growth: An Immigration Strategy for Newfoundland and Labrador (St. John's: Human Resources, Labour, and Employment, 2007), accessed 25 October 2009, http://www.nlimmigration.ca/media/2842/ strategydoc-mar07.pdf.

2. Canada, Citizenship and Immigration Canada, Canada Facts and Figures: Immigrant Overview Permanent and Temporary Residents (Ottawa: Citizenship and Immigration Canada, 2010), 31.

3. Goss Gilroy, Retention and Integration of Immigrants, 19.

4. Canada, Citizenship and Immigration Canada, Research and Evaluation, Ima Okonny-Meyers, The Interprovincial Mobility of Immigrants in Canada (Ottawa: Citizenship and Immigration Canada, 2010), 4.

5. Canada, Canada Facts and Figures, 30.

6. Keith Banting and Will Kymlicka, "Canadian Multiculturalism: Global Anxieties and Local Debates," British Journal of Canadian Studies 28 (2010): 43-72.

7. Ibrahim M. Alladin, Racism in Canadian Schools (Toronto: Harcourt Brace Canada, 1996).
8. "March 21st, International Day for the Elimination of Racial Discrimination," Ipsos Reid and the Dominion Institute, accessed January 31, 2013, http://www.dominion .ca/Downloads/IRracismSurvey.pdf.

9. Russell W. Rumberger, "Dropping Out of High School: The Influence of Race, Sex, and Family Background," American Educational Research Journal 20 (1983): 199-220; Ruben G. Rumbaut, "The Crucible Within: Ethnic Identity, SelfEsteem, and Segmented Assimilation Among Children of Immigrants," International Migration Review 28 (1994): 748-794; Rodney Clark, Norman B. Anderson, Vernessa R. Clark, and David R. Williams, "Racism as a Stressor for African Americans: A Biopsychosocial Model," American Psychologist 54 (1999): 805-816; Toni Terling Watt and Susan F. Sharp, "Race Differences in Strains Associated with Suicidal Behavior among Adolescents," Youth and Society 34 (2002): 232-256.

10. Manju Varma-Joshi, Cynthia J. Baker, and Connie Tanaka, "Names Will Never Hurt Me?" Harvard Educational Review 74 (2004): 176.

11. As the interviews were conducted between May and June 2007, it is important to note that this research occurred well before the adoption in 2012 of Protecting Canada's Immigration System Act. While this legislation will no doubt influence all categories of immigration (including refugees), the implication of those changes are not discussed in this paper.

12. The 2011 census estimated that the St. John's CMA had a population of 196,966 while the 2006 Census estimated that it had a population $181,113$.

13. Cynthia J. Baker, Manju Varma-Joshi, and Connie Tanaka, "Sticks and Stones: Racism as Experienced by Adolescents in New Brunswick," Canadian Journal of Nursing Research 33 (2001): 87-105.

14. Canada, Statistics Canada, "Population and Dwelling Counts, for Census Metropolitan Areas and Census Agglomerations, 2011 and 2006 Censuses" (Ottawa: Statistics Canada, 2011), accessed January 31, 2013, http:// www12.statcan.gc.ca/census-recensement/2011/dp-pd/ hlt-fst/pd-pl/Table-Tableau.cfm?LANG=Eng\&T=201\&S= $3 \& \mathrm{O}=\mathrm{D} \& \mathrm{RPP}=150$.

15. Canada, Statistics Canada, "Immigrant Population by Place of Birth, by Province and Territory (2006 Census)" (Ottawa: Statistics Canada, 2006), accessed February 10, 2013, http://www.statcan.gc.ca/tables-tableaux/sum-som/ 101/cst01/demo34b-eng.htm. Please note that these estimates are based on the 2006 census data as the 2011 numbers were unavailable.

16. UNESCO, "UNESCO: Acting with and for Youth," accessed February 10, 2013, http://www.unesco.org/new/en/social -and-human-sciences/themes/youth/.; Canada. Statistics Canada, "National Longitudinal Survey of Children and Youth" (Ottawa: Statistics Canada, 2010), accessed February 10, 2013, http://www23.statcan.gc.ca/imdb/p2SV.pl?Functi on=getSurvey\&SDDS=4450\&Item_Id=25609\&lang=en. 
17. Canada, Statistics Canada, "Community Profiles (2006 Census)" (Ottawa: Statistics Canada, 2006), accessed May 27, 2013, http://www12.statcan.gc.ca/census-recensement/2006/dp-pd/prof/92-591/details/page.cfm?Lang=E\& Geo $1=$ CMA \&Code $1=001 \&$ Geo $2=$ PR \&Code $2=10 \& D$ ata $=$ Count\&SearchText=St.\%20John\%27s\&SearchType=Begins $\&$ SearchPR $=01 \& \mathrm{~B} 1=$ All \&GeoLevel $=$ PR \&GeoCode $=001$.

18. Jean L. Kunz, Ann Milan, and Sylvain Schetagne, "Unequal Access: A Canadian Profile of Education, Employment and Income" (Ottawa: Canadian Race Relations Foundation, 2000), accessed February 12, 2013, http://www.crr.ca/ images/stories/pdf/unequal/Engfin.pdf.

19. Norman Denzin and Yvonna S. Lincoln, eds., The Handbook of Qualitative Research, 2nd ed. (Thousand Oaks: Sage Publications, 2000).

20. Varma-Joshi, Baker, and Tanaka, "Names Will Never Hurt $\mathrm{Me}$ ?" 180.

21. Marion Allen and Louise Jensen, "Hermeneutical Inquiry: Meaning and Scope," Western Journal of Nursing Research 12 (1990): 243.

22. Michael James, "Race," in The Stanford Encyclopedia of Philosophy (Winter 2012 ed.), ed. Edward N. Zalta, accessed February 12, 2013, http://plato.stanford.edu/archives/ win2012/entries/race/.

23. Ian Law, Racism and Ethnicity: Global Debates, Dilemmas, Directions (Harlow: Pearson Education, 2010), 5.

24. Ibid.

25. June Ying Yee, "Racism, Types of," in Encyclopedia of Race, Ethnicity and Society, ed. Richard T. Schaefer (Thousand Oaks: Sage Publications, 2008), 1119.

26. Ibid., 1120.

27. Marie Gillespie and Jason Toynbee, Analysing Media Texts (London: Open University Press, 2006).

28. John F. Dovidio and Samuel L. Gaertner, "Aversive Racism," in Encyclopedia of Race, Ethnicity \& Society, ed. Richard T. Schaefer (Thousand Oaks: Sage Publications, 2008), 1116.

29. Teun A. van Dijk, "New(s) Racism: A Discourse Analytical Approach," in Ethnic Minorities and the Media, ed. Simon Cottle, (Philadelphia: Open University Press, 2000), 33.

30. Martin Barker, The New Racism (London: Junction Books, 1981).

31. Phil Fontaine, Modern Racism in Canada (Kingston, ON: Queen's University Press, 1998).

32. Frances Henry, Carol Tator, Winston Mattis, and Tim Rees, The Colour of Democracy: Racism in Canadian Society, 2nd ed. (Toronto: Harcourt Brace, 2000), 55.

33. Shelly P. Harrell, "A Multidimensional Conceptualization of Racism-Related Stress: Implications for the Well-Being of People of Color," American Journal of Orthopsychiatry 70 (2000): 42-57.

34. Frances Henry, Carol Tator, Winston Mattis, and Tim Rees, The Colour of Democracy: Racism in Canadian Society, 3rd ed. (Toronto: Thomson Nelson, 2006), 27.
35. Philomena Essed, Understanding Everyday Racism: An Interdisciplinary Theory (Newberry Park: Sage Publications, 1991).

36. Ibid., 77; emphasis in original.

37. It should be noted that the author was not wholly convinced that the respondent was referring to a student in his class. Varying cues and specific responses to other questions seem to suggest that the student was, in fact, describing his own experience.

38. Henry et al., 2nd ed., 27.

39. Following the example of Essed, this article does not spell out racial slurs unless it is necessary for comprehension.

40. Leslie Picca and Joe Feagin, Two-faced Racism: Whites in the Backstage and Frontstage (New York: Routledge, 2007), 80; emphasis in original.

41. George Dei, Josephine Mazzuca, Elizabeth McIssac, and Jasmine Zine, Reconstructing 'Drop-out': A Critical Ethnography of the Dynamics of Black Students' Disengagement from School (Toronto: University of Toronto Press, 1997); James H. Carter, "Racism's Impact on Mental Health," Journal of the National Medical Association 86 (1994): 543-547; S. Fernando, "Racism as a Cause of Depression," International Journal of Social Psychiatry 30 (1984), 41-49.

42. Ami Rokach and Felix Neto, "Causes of Loneliness in Adolescence: A Cross-Cultural Study," International Journal of Adolescence and Youth 8 (2000), 66.

43. T. Brennan, "Loneliness at Adolescence," in Loneliness: A Sourcebook of Current Theory, Research, and Therapy, ed. Letitia Peplau and Daniel Perlman (New York: Wiley, 1982), 269-296.

44. Joe Feagin, Hernan Vera, and Nikitah Imani, The Agony of Education: Black Students at White Colleges and Universities (New York: Routledge, 1996).

45. Elizabeth Brondolo, Nisha Brady ver Halen, Melissa Pencille, Danielle Beatty, and Richard J. Contrada, "Coping with Racism: A Selective Review of the Literature and a Theoretical and Methodological Critique," Journal of Behavioral Medicine 32 (2009): 64-88.

46. Howard C. Stevenson, Jocelyn Reed, Preston Bodison, and Angela Bishop, "Racism Stress Management: Racial Socialization Beliefs and the Experience of Depression and Anger in African American Youth," Youth and Society 29 (1997): 197-222.

47. David Mellor, "Responses to Racism: A Taxonomy of Coping Styles used by Aboriginal Australians," American Journal of Orthopsychiatry 74 (2004): 56-71.

48. Holly White, "Settlement Workers in the Schools Program Overview" (panel presentation, Annual Meeting of the Atlantic Region of Association of Immigrant Serving Agencies (ARAISA), St. John's, NL, September 19-21, 2006).

49. Brondolo et al., "Coping with Racism," 69.

50. Irwin Sarason, Henry Levine, Robert Basham, Barbara Sarason, "Assessing Social Support: The Social Support Questionnaire," Journal of Personality and Social Psychology 44 (1983): 127-139. 
51. James Baker, "Not in My Backyard" (unpublished report prepared for the Association for New Canadians, 2008), 3.

52. W. Warren, E. Samuel, M. King, and J. Yealland, Study of Adolescents in Selected Ethnocultural Groups: School, Health and Home (Kingston, ON: Social Program Evaluation Group, 1997).

53. Harrell, "A Multidimensional Conceptualization of Racismrelated Stress," 45.

54. Baker, Varma-Joshi, and Tanaka, "Sticks and Stones," 94.

James Baker is a PhD Candidate in the Department of Sociology at Memorial University. Since 2006, he has worked as a researcher with the Association for New Canadians, a community-based, non-profit immigrant settlement agency located in St. John's, Newfoundland and Labrador.
Financial support for this research was provided by the Atlantic Metropolis Centre and the Department of Health and Community Services, Government of Newfoundland and Labrador. The author would also like to thank the Association for New Canadians for providing office space for the research and to Dr. Cynthia Baker for providing the interview schedule used in the New Brunswick study. In addition, the author is grateful for the comments and efforts of the anonymous reviewers, the efforts of the editor, as well as Robbie Bisson, who acted as the research assistant. 
(C) James Baker, 2013. This open-access work is licensed under a Creative Commons Attribution-NonCommercial 4.0 International License, which permits use, reproduction and distribution in any medium for non-commercial purposes, provided the original author(s) are credited and the original publication in Refuge: Canada's Journal on Refugees is cited. 